\title{
Dariusz Makiłła
}

University of Economics and Human Sciences in Warsaw, Poland

ORCID: 0000-0003-0775-4617

dmakilla@wp.pl

\section{Poland after the Thirteen Years' War (1454-1466): The Scope of Political and Structural Changes}

\author{
Polska po wojnie trzynastoletniej (1454-1466). Zakres zmian \\ ustrojowych i politycznych
}

\begin{abstract}
The war of Poland with the Teutonic Knights Order in the years 1454-1466, ended with the peace of Torun 1466, had a significant impact on the increase in the importance of Poland's position in Europe, which was reflected in the subordination of the defeated Teutonic Order state in Prussia and Poland's obtaining a dominant position in Central and Northern Europe. Above all, however, events that took place during the war, especially the political crisis caused by claims of the nobility gathered for war as part of the levy in mass and the issuing of privileges for the nobility in 1454 initiated the start of changes in the political system of the Kingdom of Poland, which led to transformations in the structures of state assemblies and the creation of the new power system. The result of the transformation processes initiated at that time was the establishment in 1468 of a nationwide bicameral parliament, based on the representation of territorial assemblies, whose convocation was, moreover, due to the need to solve the financial problems arising as a result of the war, which ended in 1466. The war of 1454-1466 had a real impact on the formation of a new political structure of the Kingdom of Poland, whose development was continued in the $16^{\text {th }}$ century.
\end{abstract}

Keywords: the Thirteen Years' War; political system; bicameral parliament; privileges for the nobility; Kingdom of Poland

CORRESPONDENCE ADDRESS: Dariusz Makiłła, PhD, dr. habil., Associate Professor, University of Economics and Human Sciences in Warsaw, Okopowa 59, 01-043 Warszawa, Poland. 
The course of the Thirteen Years' War (1454-1466), started actually with the issue by King Kazimierz Jagiellończyk on 6 March 1454 a privilege incorporating the lands of the Teutonic Knights Order in Prussia to the Kingdom of Poland, ${ }^{1}$ and ended with peace in Torun on 19 October $1466,{ }^{2}$ militarily confused and changeable, taking place in northern Poland and in Prussia - is generally well known. ${ }^{3}$ So it doesn't need to be reported meticulously, although it will be necessary to refer to certain aspects of it.

A much more noteworthy issue is the consideration of the Thirteen Years' War of 1454-1466 from the perspective of its historical and political conditions, but also, and perhaps above all, the consequences that this war caused in the broad sphere of political and legal relations in the Kingdom of Poland, but also in Central, Northern and Eastern Europe. Like any major international conflict, the war of 1454-1466 had its basis and causes, revealing at the same time the significant impact of the policy implemented during this war on the shaping of a specific political system in Poland in the $15^{\text {th }}$ century. In this sense, the peace of Torun (1466), but also the entire Thirteen Years' War (1454-1466) undoubtedly ended an era in the mid-15 $5^{\text {th }}$ century, and at the same time opened a second one.

Let us try to briefly present the most important conditions, associated with its outbreak, course and termination, while having far-reaching effects in the development of political and political relations in the Kingdom of Poland.

II.

First of all, as a result of the war, and then the peace it resulted in, there was a change in the balance of power in international relations. The rivalry lasting for many decades for domination in the north-central part of Europe between the Teu-

${ }^{1}$ M. Biskup, Do genezy inkorporacji Prus, „Przegląd Zachodni” 1954, no. 7-8, pp. $293-$ 306; idem, Zjednoczenie Pomorza Wschodniego z Polska w połowie XV wieku, Warszawa 1959, pp. 278-331; A. Vetulani, Lenno pruskie. Od traktatu krakowskiego do śmierci księcia Albrechta 1525-1568, Kraków 1930, pp. 13-42; idem, Rokowania krakowskie z r. 1454 i zjednoczenie ziem pruskich z Polska, „Przegląd Historyczny” 1954, vol. 45(2/3), pp. 188-236. See also in another way: E. Weise, Die staatsrechtlichen Grundlagen des zweiten Thorner Friedens und die Grenzen seiner Rechtmäßigkeit, „Zeitschrift für Ostforschung“"1954, no. 1, pp. 1-25; S. Dolezel, Der zweite Thorner Frieden (1466) in der polnischen und preussischen politischen Argumentation des 16. Jahrhunderts, „Analecta Cracoviensia” 1975, vol. 7, pp. 265-273.

2 M. Biskup, Trzynastoletnia wojna z Zakonem Krzyżackim 1454-1466, Warszawa 1967, pp. 698-703. On the peace negotiations in Toruń, see J. Długosz, Annales, Liber XII, part 2: 1462 1480, ed. J. Wyrozumski [et al.], Kraków 2005, p. 160; Johann Lindaus Geschichte des dreizehnjähriges Krieges, ed. T. Hirsch, [in:] Scriptores rerum Prussicarum, vol. 4, Leipzig 1870, pp. 628-637.

${ }^{3}$ M. Biskup, Trzynastoletnia wojna... 
tonic Order and Poland had already before its great solstice in the years 1409-1411, ending with breaking the power of the Order after the war 1454-1466. Although the war did not diminish the Teutonic Order state at that time, it brought financial problems, caused international difficulties, weakened the Order internally, and induced grassroots social movements. The latter led to the creation of an estate opposition within the Teutonic Order state, which eventually came out politically and armed against the Order, ${ }^{4}$ surrendering to the Polish king in 1454. As a result of losing the war in 1466, the Order still remained, without being subject to liquidation, but while maintaining the legal state of incorporation of the lands of Teutonic Order state on the Polish side, the territory left at peace to the Order was separated from the whole and given for its use. ${ }^{5}$ In a legal sense, the territorially reduced and politically weakened monastic state in Prussia after 1466 was subordinated to the supreme power of the Polish king based on feudal-like relations. ${ }^{6}$ In this sense, the Thirteen Years' War was one of the few cases determining the balance of power, eliminating the importance of certain entities, and putting others ahead. In this case, one of the subjects, the Teutonic Order state, was subordinated to the other of the competing entities, which does not mean that in practice the exercise of this authority did not exclude resistance from the Teutonic Order state in later years, ${ }^{7}$ leading to another armed conflict in $1519-1521^{8}$, which ended the liquidation of

${ }^{4}$ Idem, Zjednoczenie Pomorza Wschodniego z Polska..., p. 15 ff.; K. Górski, Początki reprezentacji rycerstwa w stanach państwa krzyżackiego w Prusach w XV w., „Zapiski Historyczne” 1966, no. 3, pp. 131-150; idem, La Ligue des Etats et es origins du règime reprèsentatif en Prusse, “Ancien Pays et Assemblées d'Etats” 1960, vol. 22, pp. 175-186 (also in: Communitas, Princeps, Corona Regni. Studia selecta, Warszawa 1976, pp. 32-41).

5 A. Vetulani, Lenno pruskie..., pp. 13-42; W. Hejnosz, Prawnopaństwowy stosunek Prus do Korony w świetle aktu inkorporacyjnego z r. 1454, „Przegląd Zachodni” 1954, no. 7-8, pp. 307-330.

${ }^{6}$ K. Górski, Późny feudalizm. Próba definicji, „Acta Universitatis Nicolai Copernici. Historia" 1982, vol. 18, pp. 9-10; A. Vetulani, Lenno pruskie..., pp. 13-42; W. Hejnosz, Traktat toruński z 1466 r. i jego prawnopolityczne znaczenie, „Zapiski Historyczne” 1966, no. 3, pp. 91-108; D. Makiłła, Status prawno-polityczny Prus Krzyżackich wobec Korony po 1466 r., [in:] Polska i ziemie pruskie po pokoju toruńskim (1466). Skutki i znaczenie dla ziem pruskich, ed. D. Makiłła, Warszawa 2017, pp. 17-28.

${ }^{7}$ K. Forstreuter, Vom Ordensstaat zum Fürstentum. Geistige und politische Wandlungen im Deutschordensstaate Preußen unter den Hochmeistern Friedrich und Albrecht (1498-1525), Kitzingen-Main 1950, pp. 12-59; L. Dralle, Der Staat des Deutschen Ordens in Preussen nach dem II. Thorner Frieden. Unternehmungen zur ökonomischen Geschichte Altpreußens zwischen 1466 und 1497, Wiesbaden 1975. On the approach to implementing the Treaty of Torun, see E. Weise, op. cit., pp. 1-25; M. Biskup, Zagadnienie ważności i interpretacji traktatu toruńskiego 1466 r., „Kwartalnik Historyczny" 1962, no. 2, pp. 295-332; A. Vetulani, Lenno pruskie..., pp. 13-42; A. Szweda, Princeps et consiliarius Regni Poloniae. Król i wielki mistrz w latach 1466-1497, [in:] Od traktatu kaliskiego do pokoju oliwskiego. Polsko-krzyżacko-pruskie stosunki dyplomatyczne w latach 1343-1660, ed. A. Bues, Warszawa 2014, pp. 241-258.

${ }^{8}$ M. Biskup, ,Wojna pruska”, czyli wojna Polski z zakonem krzyżackim z lat 1519-1521. Uźródet sekularyzacji Prus Krzyżackich, part 2, Olsztyn 1991, passim. 
the state of the Order and the new regulation of the legal relationship of the territory remaining after the Teutonic Order (in the Cracow Treaty of 8 April 1525) ${ }^{9}$. However, the reduction of the rival's position in 1466 paved the way for Poland's growing importance on an international scale. At the same time, however, it also led to far-reaching internal changes, transforming Poland in every respect into a power in contemporary sense. The removal of the Teutonic Order state after the war ended in 1466 from the circle of direct neighbors who had been also absorbed Polish forces, as well as the interest in Polish policy, laid the foundations for the Jagiellonians in the future to embark on a large-European dynastic policy and for them to take over the thrones of the Czech (1471) and Hungary (1490). Victory over the Teutonic Order also strengthened - although in the departed war Lithuania remained neutral - the position of the Jagiellonian rulers in their own domain.

III.

The second significant result of the Thirteen Years' War which took place during its duration - because the war did not start the process itself, as it has going on for a long time - was, however, a clear acceleration of the process leading to changes in power system and internal structure in the Kingdom of Poland. The attempt an armed entry of the royal army into the territory of Order state to stop the Teutonic army heading for Prussia was preceded by the transformation of the Greater Poland province levy in a mass expedition into the camp parliament (sejm) in Cerekwica, and ended in a military defeat of the levy in mass forces at the battle of Chojnice (September 18, 1454)..$^{10}$

9 A. Werminghoff, Der Hochmeister des Deutschen Ordens und das Reich bis zum Jahre 1525, „Historische Zeitschrift“ 1913, vol. 110, pp. 507-512; W. Pociecha, Geneza hotdu pruskiego, Gdynia 1937, pp. 1 ff., especially pp. 133-142; W. Hubatsch, Albrecht von Brandenburg-Ansbach. Deutschordens Hochmeister und Herzog in Preussen 1490-1568, Heidelberg 1960, p. 76 ff., especially pp. 131-137; H. Freiwald, Markgraf Albrecht von Ansbach-Kulmbach und seine landständische Politik als Deutschordens Hochmeister und Herzog in Preussen während der Entscheidungsjahre 1521-1528, Kulmbach 1961, pp. 85-121; S. Dolezel, Das preussisch-polnische Lehnsverhältnis unter Herzog Albrecht von Preussen (1525-1568), Köln 1967, p. 15 ff., especially pp. 15-31; M. Biskup, Geneza i znaczenie hołdu pruskiego 1525 r., „Komunikaty Mazursko-Warmińskie” 1975, no. 4, pp. 407-424; idem, Polska a Zakon Krzyżacki w Prusach w początkach XVI w. Uźródet sekularyzacji Prus Krzyżackich, Olsztyn 1983; J. Małłek, Hołd pruski 1525 roku. Ostateczna likwidacja zakonu krzyżackiego w Prusach, [in:] idem, Dwie części Prus. Studia z dziejów Prus Ksiązęcych i Prus Królewskich w XVI i XVII wieku, Olsztyn 1987, pp. 31-38; J. Wijaczka, Traktat krakowski z 1525 r. Sukces Jagiellonów czy Hohenzollernów, [in:] Od traktatu kaliskiego do pokoju oliwskiego ..., pp. 283-294; D. Makiłła, Ustanowienie lenna pruskiego w 1525 r. Odstępstwo od traktatu toruńskiego czy jego kontynuacja?, „Komunikaty Mazursko-Warmińskie” 2017, no. 2, pp. 265-277.

${ }^{10}$ S. Roman, Przywileje nieszawskie, Wrocław 1957, pp. 146-160. 
The aim to calm the stormy atmosphere at the sejm formed in the camp near Cerekwica, before the invasion of the Polish army in the borders of the Teutonic Order state, threatening as a result of the conditions imposed by the nobility by inhibiting the king's war plans, came at the price of granting him privileges of a decidedly political nature. Although these privileges were initially issued only for the province of Greater Poland (September 15, 1454), which constituted the main part of the levy in mass forces, which was the basis of the royal army at the time, it initiated the process of extending these privileges, with some modifications, to other provinces, which took place within 1454 and during the proceeded war. ${ }^{11}$ Their granting to particular lands was to guarantee the king ad hoc support for continuing military operations against the Order.

In the political sense, provincial estates were handed over in privileges of 1454 two important competences regarding tax and military matters, making the imposition of taxes and calling a levy in mass forces conditional upon the consent of land assemblies. In addition, a ban was introduced on combining the office of a voivode and a castellan with the office of a starost, a guarantee was granted to the gentry of Great Poland's province for equal treatment with the Lesser Poland province in gaining access to court offices, it was also forbidden to pledge of castle starosties, but the voivods were given the right to impose a tax on craft products in cities, and castellans were deprived of castellan courts over part of the nobility. ${ }^{12}$

The privileges of 1454 strengthened the territorial structure of the kingdom created in the process of unification from the $14^{\text {th }}$ century, and expanded in the course of the $15^{\text {th }}$ century, which was vertically subordinate to the royal sovereignty, exercising common, homogeneous power over particular lands, extending simultaneously - which had its meaning - on the territory of the whole united kingdom. At the same time, in the privileges of 1454, the transfer of some royal powers to regional assemblies, in turn, resulted in their introduction in the form of formalized and institutionalized estate assemblies, as a parallel subject of power in the structure of the state, which led to the creation of a dualistic power system in individual territories on the ground of king and regional assemblies basis, but at the same time existed throughout the whole kingdom. Privileges, in which certain

11 M. Bobrzyński, O ustawodawstwie nieszawskim Kazimierza Jagiellończyka, Kraków 1873, pp. 146-166; A. Prochaska, Geneza i rozwój parlamentaryzmu za pierwszych Jagiellonów, Kraków 1899, p. 141 ff.; W. Smoleński, Przywilej cerekwicki, [in:] Pisma historyczne, Warszawa 1901, pp. 487-493; A. Kłodziński, W sprawie przywilejów nieszawskich z r. 1454, [in:] Studya historyczne wydane ku czci prof. Wincentego Zakrzewskiego, Kraków 1908, pp. 241-273; J. Siemieński, Od sejmików do sejmu 1454-1505, [in:] Studia historyczne ku czci Stanisława Kutrzeby, vol. 1, Kraków 1938, pp. 445-460; S. Roman, op. cit., pp. 116-137; W. Hejnosz, Przywileje nieszawsko-radzyńskie dla ziem ruskich, [in:] Studia historyczne..., pp. 233-246; K. Górski, Rycerstwo i szlachta wobec możnowtadztwa w XIV i XV wieku, „Kwartalnik Historyczny” 1970, no. 4, pp. 840-841.

${ }_{12}$ S. Roman, op. cit., pp. 168-176. 
powers of the royal authority were transferred to the regional councils, became a factor enabling the shift of the current center of gravity from the king and the Council of the Kingdom, organized and operating earlier, which at the same time not being liquidated, but subjected only to further transformations, remained a separate factor power - on the arrangement of the king and state territorial assemblies. Convening territorial state assemblies was not only possible in this situation, but also became necessary for the functioning of the state. Thus, the privileges of 1454 were in this process an instrument of legal unification of the kingdom. The scope of matters transferred to the regional councils in the privileges of 1454 became at the same time the joint scope of power of the monarch and the estate assemblies, which were the regional councils, thus acquiring public-law significance. In this way, the regional councils became organs participating in the exercise of power, which constituted an important change in the political system of the kingdom, opening the way for its further structural evolution. ${ }^{13}$ Admittedly, territorial state assemblies have already appeared in Poland in the form of various conventions, most often in several varieties (land assemblies, ${ }^{14}$ provincial assemblies ${ }^{15}$ ), which

13 W. Knoppek, Zmiany w uktadzie sit politycznych w Polsce $w$ drugiej połowie XV wieku i ich zwiazek z geneza dwuizbowego sejmu, „Czasopismo Prawno-Historyczne” 1955, no. 1, pp. 55-95; K. Górski, Rzady wewnętrzne Kazimierza Jagiellończyka w Koronie, „Kwartalnik Historyczny” 1959, no. 3, pp. 726-756.

${ }_{14}$ A. Pawiński, Sejmiki ziemskie, początek ich i rozwój aż do ustalenia się posłów ziemskich w ustawodawstwie sejmu walnego, Warszawa 1895; A. Prochaska, op. cit., p. 88 ff.; F. Piekosiński, Wiece, sejmiki, sejmy i przywileje ziemskie w Polsce wieków średnich, Kraków 1900, pp. 171-251; $\mathrm{K}$. Górski, Les dèbuts de la representation de la communitas nobilium dans les assemblées s'états de l'est europèen, “Ancien Pays et Assemblées d'Etats" 1968, vol. 47 (also in: Communitas, Princeps, Corona Regni..., pp. 72-75); idem, Institutions représentatives et l'emancipation de la noblesse. Pour une typologie des assembler d'états au XVe siècle, „Êtudes présentées á la Commission Internationale pour l'Histoire des Assemblées d'Êtats" 1975, vol. 52; S. Russocki, Narodziny polskiego parlamentaryzmu w perspektywie porównawczej, [in:] Społeczeństwo obywatelskie i jego reprezentacja (1493-1993), ed. J. Bardach, participation W. Sudnik, Warszawa 1995, pp. 32-47, especially pp. 35-41; idem, Od roków monarszych do zgromadzeń stanowych, [in:] Cultus et cognitio. Studia z dziejów średniowiecznej kultury, ed. S.K. Kuczyński, Warszawa 1976; idem, Poczatki Zgromadzeń Stanowych w Europie Środkowej, „Przegląd Historyczny” 1975, vol. 66(2), pp. 171-187.

${ }_{15}$ Convening provincial assemblies was more convenient for the king. It allowed the king to come personally to one assembly in the province, to which nobles came from several lands in significant numbers, enabling them to gain an advantage over local dignitaries who were members of the kingdom council and were often in conflict with the king. Only if the king could not come in person did the monarch's interests be represented by "gentlemen council". Provincial assemblies gained great importance, especially after 1454. They contacted each other often to agree on their position towards the monarch. Particularly this was done by parliaments in tax matters, but also over time in matters of royal land administration (alienation of these goods, pledges, leases), customs or salt prices, which mining was the royal regal privilege. Provincial assemblies did this by sending their own representatives, which in turn contributed to the origins of the representation system based on the actions of proxies. In addition, provincial assemblies performed important judicial functions, which were performed by the king as the supreme judge or a group of local dignitaries during his 
depended on the purpose of the assembly, the way he was released, and thus the territorial scope resulting from these factors, but they did not have the position they obtained after 1454. After the Thirteen Years' War, and even during it, these assemblies assumed from the royal point of view the role of exchange assemblies, i.e. those where the king, intending to achieve his political goals, temporarily used them interchangeably depending on the circumstances and needs. However, this solution turned out to be only a short-term and uncommon practice.

The effect of political changes that arose in the Polish state during the Thirteen Years' War was primarily a gradual structural unification of the territories that were part of the kingdom, which resulted in the creation of homogeneous power throughout the entire country. The tendency to unify and give the kingdom a vertical structure appropriate for estate composed states was consolidated by giving meaning and a new shape to the general assembly, known as the institution of the convention of all those entitled from the end of the $14^{\text {th }}$ century. The general assembly appointed in the $15^{\text {th }}$ century gained the role and the significance of the superior nationwide assembly, large and direct, in this period ${ }^{16}$, covering the entire territory of the state, although during the shaping of the vertical system of territorial assemblies functioning in individual lands, the king - as has already been mentioned - sometimes appealed but less in the second half of the $15^{\text {th }}$ century, interchangeably to the provincial assemblies.

The factor that ultimately accelerated the establishment of the estate assemblies was the financial difficulties of the state (and these matters fell under the joint authority of the king and estate assemblies). The reason for the difficulties were financial obligations arising as a result of the war of 1454-1466, related to the need to satisfy the claims of mercenary soldiers. They prompted King Kazimierz

absence. Thus, the sentences that were passed in provincial assemblies, involving representatives of more lands, had greater weight. Legislation also began to play an important role in the activities of provincial assemblies, especially when it concerned estate rights, which had to be agreed each time. The unspecified competence of provincial and general assemblies allowed the ruler in the second half of the $15^{\text {th }}$ century to make an alternative choice between them. Making arrangements with one province may have been an argument for the king in talking to the other province to achieve his demands. After the strengthening of the position by the regional councils, which followed the issue of privileges from 1454, the nobility tended to send to assemblies, also provincial, more of their representatives elected at the regional councils, rather than arriving directly in crowds to provincial assemblies, which began to transform at the end of the $15^{\text {th }}$ century in principle. This contributed to the renewal of the importance of general sejms, whose functioning at the turn of the $15^{\text {th }}$ and $16^{\text {th }}$ centuries was based on representation, pushing aside the role of provincial sejms as an intermediate assembly between the sejms, electing deputies to the sejm and the sejm itself, which eventually evolved after 1505, adopting the Nihil Novi constitution in a central state body. See J. Siemieński, op. cit., pp. 445-460; J. Bardach, Poczatki sejmu, [in:] Historia sejmu polskiego, vol. 1: Do schytku szlacheckiej Rzeczypospolitej, ed. J. Michalski, Warszawa 1984, pp. 35-36.

16 J. Bardach, O genezie sejmu polskiego, [in:] VIII Powszechny Zjazd Historyków Polskich, Sekcja 7: Historia Państwa i Prawa, Warszawa 1959, pp. 526-533; idem, Poczatki..., pp. 13-28. 
Jagiellończyk in 1468 to make an unambiguous decision to convene one nationwide assembly to Piotrków. It was preceded by meetings of King Kazimierz with dignitaries and nobility at the provincial assemblies, Lesser Poland in Wiślica on 25-30 June 1468 and Greater Poland in Koło on 13 July 1468. Both in the Lesser Poland provincial assembly in Wiślica as well as the Greater Poland in Koło, it was granted to the king's request, postponing the final decision to the sejm, which was appointed, as was settled by Wacław Uruszczak, on 9 October 1468. At the same time, the king ordered the election of two noble deputies at each poviat assemblies throughout the Kingdom, who would then come to Piotrków to participate in general assembly. The king, council members and deputies elected at the regional councils met in the sejm, which began its session just on 9 October 1468. Various matters were taken up during the deliberations, but it was sent to envoys from individual lands that the king approached them with members of the council of the Kingdom about finding a way to pay the soldiers their outstanding pay. However, the envoys stated that they did not have the appropriate mandate to decide on helping the king pay the arrears to soldiers. In this situation, the sejm did not make any decision on this matter, but sent it back to the provincial assemblies, which were to be held on strictly defined dates: the general assembly in Koło for the Greater Poland on St. Nicholas, i.e. on December 6, and the general assembly of Lesser Poland in the Nowe Miasto Korczyn on the day of the Conception of the Virgin Mary, i.e. December 8, 1468. An appropriate resolution on granting aid to the Kingdom was adopted at the provincial general assembly in Nowe Miasto Korczyn on 8 December 1468 , to which also envoys from Greater Poland came. In this way, the practice of sitting in the sejm with the participation of deputies elected at the regional councils, constituting a separate chamber - and not only through the participation of the sejm delegation of provincial general assemblies, or through the personal participation of each of the nobility in general - became established in the following sejms during the reign of King Kazimierz, which took place every year, acquiring the character of a permanent rule for the organization of the sejm. ${ }^{17}$

The result of the establishment of the state-wide assembly was the hierarchy of estate assemblies, functioning in an earlier territorial structure in a horizontal system, consisting in their vertical arrangement, and in principle subordination of the existing territorial assemblies to the national assembly. In practice, the activity of territorial assemblies began to be resolved to limiting their activities to fulfilling specific functions: the election of a deputy as a functional link between the regional council and the nationwide assembly and the definition of regional council instructions as an act serving the implementation of regional council resolutions. At the

${ }^{17}$ W. Uruszczak, Najstarszy sejm walny koronny ,, dwuizbowy” w Piotrkowie w 1468 roku, [in:] Narodziny Rzeczypospolitej. Studia z dziejów średniowiecza i czasów wczesnonowożytnych, eds. W. Bukowski, T. Jurek, vol. 1, Kraków 2012, pp. 1033-1056. 
same time, a Council of Kingdom was directly involved in the nationwide assembly, which became a separate chamber for the duration of the sejm, cooperating with the king who often took part in the nationwide assembly. In turn, the nobility retained their personal participation in the sessions of the regional councils, which were part of the vertical structure of the state assemblies of the kingdom.

In this way, the war of 1454-1466 launched a process of legal and political changes, progressing in certain stages, which led to the creation of a state representation body in the form of a nationwide assembly, including envoys of regional councils, forming a separate chamber, the Council of Kingdom and the king - although this arrangement was subject to the future of evolution-leading to the sejm playing a centralizing function in the state. ${ }^{18}$

\section{IV.}

And two more consequences of the Thirteen Years' War 1454-1466, about a different, but also important for the existence and functioning of the Kingdom of Poland.

The initial defeats of the royal army in Prussia operating in the levy in mass system caused execution of the significant changes in the Polish military system. The levy in mass remained the main foundation of the army, based on the state's duty of military service resulting from the possession of land, which had its sources in knighthood law (ius militare) and in subsequent universal privileges for the entire state from $1355,1374^{19}, 1388^{20}$. This duty, not questioned by the nobility, constituted the basis of its significance and title to play a political role, such as during the interregnum in 1573, when having the duty to participate in the levy in mass forces became the reason for exercising the right to participate in the election. ${ }^{21}$ However, the experience of the Thirteen Years' War has shown that the main burden of warfare must be transferred to a professional army, partly permanent, prepared

${ }_{18}$ J. Bardach, Poczatki..., pp. 47-62; K. Grzybowski, Teoria reprezentacji w Polsce epoki Odrodzenia, Warszawa 1959.

19 P. Skwarczyński, Z badań nad przywilejami ziemskimi budzińskim i koszyckim, Lublin 1936; idem, Zagadnienie wplywów węgierskich na przywileje ziemskie drugiej połowy XIV w., „Teki Historyczne" 1949, vol. 3(3-4), pp. 125-155; D. Bagi, Wptywy i znaczenie szlachty polskiej $i$ wegierskiej pod koniec XIV wieku. Próba porównania przywileju budzińskiego z 1335 r. z przywilejem koszyckim z 1374 r. w świetle potwierdzenia Złotej Bulli, [in:] Polska i Węry w kulturze i cywilizacji europejskiej, ed. J. Wyrozumski, Kraków 1997, pp. 35-47; J.S. Matuszewski, Przywileje i polityka podatkowa Ludwika Wegierskiego, Łódź 1983.

${ }^{20}$ M. Handelsman, Przywilej piotrkowski 1388, „Przegląd Historyczny” 1907, vol. 4, pp. 20-36, 149-157, 349-362.

${ }^{21}$ D. Makiłła, Artykuly henrykowskie (1573-1576). Geneza - obowiazywanie - stosowanie. Studium historyczno-prawne, Warszawa 2012, pp. 132-157, 330-338. 
and capable of undertaking military operations. ${ }^{22}$ Although the discussion on the organization of a permanent armed force has still been continued during the parliamentary debates in the $16^{\text {th }}$ century, but the direction of changes in this respect was established at that time.

In addition, the incorporation of Royal Prussia and Ermland into the Polish Kingdom after the war, opening Poland's access to the sea, initiated social and economic processes that significantly influenced the increase in the importance of the Polish Kingdom on an international scale. In Royal Prussia, in which the king took over many goods of Teutonic Order, the royal domain was significantly increased. ${ }^{23}$ At the same time, access to the sea and the development of the economy caused an increase in material importance conducive to further political emancipation of the Polish nobility.

To sum up, the Thirteen Years' War - which often happens in such situations - has become a catalyst for events whose effects proved to be far-reaching. It was essentially a case of multilateral and comprehensive influence on political and structural relations, constituting an important turning point in the development of the Polish state at the dawn of modern times.

\section{REFERENCES}

Bagi D., Wpływy i znaczenie szlachty polskiej i węgierskiej pod koniec XIV wieku. Próba porównania przywileju budzińskiego z 1335 r. z przywilejem koszyckim z 1374 r. w świetle potwierdzenia Złotej Bulli, [in:] Polska i Wegry w kulturze i cywilizacji europejskiej, ed. J. Wyrozumski, Kraków 1997. Bardach J., O genezie sejmu polskiego, [in:] VIII Powszechny Zjazd Historyków Polskich, Sekcja 7: Historia Państwa i Prawa, Warszawa 1959.

Bardach J., Poczatki sejmu, [in:] Historia sejmu polskiego, vol. 1: Do schyłku szlacheckiej Rzeczypospolitej, ed. J. Michalski, Warszawa 1984.

Biskup M., Do genezy inkorporacji Prus, ,Przegląd Zachodni” 1954, no. 7-8.

Biskup M., Geneza i znaczenie hołdu pruskiego 1525 r., „Komunikaty Mazursko-Warmińskie” 1975, no. 4.

Biskup M., Polska a Zakon Krzyżacki w Prusach w początkach XVI w. U źródet sekularyzacji Prus Krzyżackich, Olsztyn 1983.

Biskup M., Trzynastoletnia wojna z Zakonem Krzyżackim 1454-1466, Warszawa 1967.

Biskup M., ,Wojna Pruska”, czyli wojna Polski z zakonem krzyżackim z lat 1519-1521. U źródet sekularyzacji Prus Krzyżackich, part 2, Olsztyn 1991.

${ }^{22}$ Idem, Der Bruch einer Idee. Das Allgemeine Aufgebot und die Mobilisierungssysteme der Adelsrepublik Polen in der Frühen Neuzeit, [in:] Verus amicus rara avis est. Studia poświęcone pamięci Wojciecha Organiściaka, eds. A. Lityński, A. Matan, M. Mikołajczyk, G. Nancka, D. Nawrot, Katowice 2020, pp. 483-490.

${ }^{23}$ Prusy Królewskie w drugiej połowie XVI w., ed. M. Biskup, participation L. Koc, Warszawa 1961, p. 45 ff. (Atlas historyczny Polski). 
Biskup M., Zagadnienie ważności i interpretacji traktatu toruńskiego 1466 r., „Kwartalnik Historyczny" 1962, no. 2.

Biskup M., Zjednoczenie Pomorza Wschodniego z Polska w połowie XV wieku, Warszawa 1959.

Bobrzyński M., O ustawodawstwie nieszawskim Kazimierza Jagiellończyka, Kraków 1873.

Długosz J., Annales, Liber XII, part 2: 1462-1480, ed. J. Wyrozumski [et al.], Kraków 2005.

Dolezel S., Das preussisch-polnische Lehnsverhältnis unter Herzog Albrecht von Preussen (15251568), Köln 1967.

Dolezel S., Der zweite Thorner Frieden (1466) in der polnischen und preussischen politischen Argumentation des 16. Jahrhunderts, „Analecta Cracoviensia” 1975, vol. 7,

DOI: https://doi.org/10.15633/acr.2878.

Dralle L., Der Staat des Deutschen Ordens in Preussen nach dem II. Thorner Frieden. Unternehmungen zur ökonomischen Geschichte Altpreußens zwischen 1466 und 1497, Wiesbaden 1975.

Forstreuter K., Vom Ordensstaat zum Fürstentum. Geistige und politische Wandlungen im Deutschordensstaate Preußen unter den Hochmeistern Friedrich und Albrecht (1498-1525), Kitzingen-Main 1950.

Freiwald H., Markgraf Albrecht von Ansbach-Kulmbach und seine landständische Politik als Deutschordens Hochmeister und Herzog in Preussen während der Entscheidungsjahre 1521-1528, Kulmbach 1961.

Górski K., La Ligue des Etats et es origins du règime reprèsentatif en Prusse, "Ancien Pays et Assemblées d'Etats" 1960, vol. 22 (also in: Communitas, Princeps, Corona Regni. Studia selecta, Warszawa 1976).

Górski K., Les dèbuts de la representation de la communitas nobilium dans les assemblées s'états de l'est europèen, "Ancien Pays et Assemblées d'Etats" 1968, vol. 47 (also in: Communitas, Princeps, Corona Regni, Warszawa 1976).

Górski K., Institutions représentatives et l'emancipation de la noblesse. Pour une typologie des assembler d'états au XVe siècle, „Êtudes présentées á la Commission Internationale pour l'Histoire des Assemblées d'Êtats" 1975, vol. 52.

Górski K., Początki reprezentacji rycerstwa w stanach państwa krzyżackiego w Prusach w XV w., „Zapiski Historyczne” 1966, no. 3.

Górski K., Późny feudalizm. Próba definicji, „Acta Universitatis Nicolai Copernici. Historia” 1982, vol. 18.

Górski K., Rycerstwo i szlachta wobec możnowładztwa w XIV i XV wieku, „Kwartalnik Historyczny” 1970, no. 4.

Górski K., Rządy wewnętrzne Kazimierza Jagiellończyka w Koronie, „Kwartalnik Historyczny” 1959 , no. 3 .

Grzybowski K., Teoria reprezentacji w Polsce epoki Odrodzenia, Warszawa 1959.

Handelsman M., Przywilej piotrkowski 1388, „Przegląd Historyczny” 1907, vol. 4.

Hejnosz W., Prawnopaństwowy stosunek Prus do Korony w świetle aktu inkorporacyjnego z r. 1454, „Przegląd Zachodni” 1954, no. 7-8.

Hejnosz W., Przywileje nieszawsko-radzyńskie dla ziem ruskich, [in:] Studia historyczne ku czci Stanisława Kutrzeby, vol. 1, Kraków 1938.

Hejnosz W., Traktat toruński z 1466 r. i jego prawnopolityczne znaczenie, „Zapiski Historyczne” 1966, no. 3.

Hubatsch W., Albrecht von Brandenburg-Ansbach. Deutschordens Hochmeister und Herzog in Preussen 1490-1568, Heidelberg 1960.

Johann Lindaus Geschichte des dreizehnjähriges Krieges, ed. T. Hirsch, [in:] Scriptores rerum Prussicarum, vol. 4, Leipzig 1870.

Kłodziński A., W sprawie przywilejów nieszawskich z r. 1454, [in:] Studya historyczne wydane ku czci prof. Wincentego Zakrzewskiego, Kraków 1908. 
Knoppek W., Zmiany w układzie sit politycznych w Polsce w drugiej połowie XV wieku i ich związek z geneza dwuizbowego sejmu, „Czasopismo Prawno-Historyczne” 1955, no. 1.

Makiłła D., Artykuły henrykowskie (1573-1576). Geneza - obowiazywanie - stosowanie. Studium historyczno-prawne, Warszawa 2012.

Makiłła D., Der Bruch einer Idee. Das Allgemeine Aufgebot und die Mobilisierungssysteme der Adelsrepublik Polen in der Frühen Neuzeit, [in:] Verus amicus rara avis est. Studia poświęcone pamięci Wojciecha Organiściaka, eds. A. Lityński, A. Matan, M. Mikołajczyk, G. Nancka, D. Nawrot, Katowice 2020.

Makiłła D., Status prawno-polityczny Prus Krzyżackich wobec Korony po 1466 r., [in:] Polska i ziemie pruskie po pokoju toruńskim (1466). Skutki i znaczenie dla ziem pruskich, ed. D. Makiłła, Warszawa 2017.

Makiłła D., Ustanowienie lenna pruskiego w 1525 r. Odstęstwo od traktatu toruńskiego czy jego kontynuacja?, „Komunikaty Mazursko-Warmińskie” 2017, no. 2.

Małłek J., Hołd pruski 1525 roku. Ostateczna likwidacja zakonu krzyżackiego w Prusach, [in:] idem, Dwie części Prus. Studia z dziejów Prus Ksiązęcych i Prus Królewskich w XVI i XVII wieku, Olsztyn 1987.

Matuszewski J.S., Przywileje i polityka podatkowa Ludwika Węgierskiego, Łódź 1983.

Pawiński A., Sejmiki ziemskie, początek ich i rozwój aż do ustalenia się postów ziemskich w ustawodawstwie sejmu walnego, Warszawa 1895.

Piekosiński F., Wiece, sejmiki, sejmy i przywileje ziemskie w Polsce wieków średnich, Kraków 1900.

Pociecha W., Geneza hołdu pruskiego, Gdynia 1937.

Prochaska A., Geneza i rozwój parlamentaryzmu za pierwszych Jagiellonów, Kraków 1899.

Prusy Królewskie w drugiej połowie XVI w., ed. M. Biskup, participation L. Koc, Warszawa 1961.

Roman S., Przywileje nieszawskie, Wrocław 1957.

Russocki S., Narodziny polskiego parlamentaryzmu w perspektywie porównawczej, [in:] Społeczeństwo obywatelskie i jego reprezentacja (1493-1993), ed. J. Bardach, participation W. Sudnik, Warszawa 1995.

Russocki S., Od roków monarszych do zgromadzeń stanowych, [in:] Cultus et cognitio. Studia z dziejów średniowiecznej kultury, ed. S.K. Kuczyński, Warszawa 1976.

Russocki S., Początki Zgromadzeń Stanowych w Europie Środkowej, „Przegląd Historyczny” 1975, vol. 66(2).

Siemieński J., Od sejmików do sejmu 1454-1505, [in:] Studia historyczne ku czci Stanisława Kutrzeby, vol. 1, Kraków 1938.

Skwarczyński P., Z badań nad przywilejami ziemskimi budzińskim i koszyckim, Lublin 1936.

Skwarczyński P., Zagadnienie wpływów węgierskich na przywileje ziemskie drugiej połowy XIV w., „Teki Historyczne” 1949, vol. 3(3-4).

Smoleński W., Przywilej cerekwicki, [in:] Pisma historyczne, Warszawa 1901.

Szweda A., Princeps et consiliarius Regni Poloniae. Król i wielki mistrz w latach 1466-1497, [in:] Od traktatu kaliskiego do pokoju oliwskiego. Polsko-krzyżacko-pruskie stosunki dyplomatyczne w latach 1343-1660, ed. A. Bues, Warszawa 2014.

Uruszczak W., Najstarszy sejm walny koronny ,, dwuizbowy” w Piotrkowie w 1468 roku, [in:] Narodziny Rzeczypospolitej. Studia z dziejów średniowiecza i czasów wczesnonowożytnych, eds. W. Bukowski, T. Jurek, vol. 1, Kraków 2012.

Vetulani A., Lenno pruskie. Od traktatu krakowskiego do śmierci księcia Albrechta 1525-1568, Kraków 1930.

Vetulani A., Rokowania krakowskie z r. 1454 i zjednoczenie ziem pruskich z Polska, „Przegląd Historyczny" 1954, vol. 45(2/3).

Weise E., Die staatsrechtlichen Grundlagen des zweiten Thorner Friedens und die Grenzen seiner Rechtmäßigkeit, ,Zeitschrift für Ostforschung“"1954, no. 1. 
Werminghoff A., Der Hochmeister des Deutschen Ordens und das Reich bis zum Jahre 1525, „Historische Zeitschrift“ 1913, vol. 110, DOI: https://doi.org/10.1524/hzhz.1913.110.jg.473.

Wijaczka J., Traktat krakowski z 1525 r. Sukces Jagiellonów czy Hohenzollernów, [in:] Od traktatu kaliskiego do pokoju oliwskiego. Polsko-krzyżacko-pruskie stosunki dyplomatyczne w latach 1343-1660, ed. A. Bues, Warszawa 2014.

\begin{abstract}
ABSTRAKT
Wojna Polski z zakonem krzyżackim w latach 1454-1466, zakończona pokojem toruńskim w 1466 r., miała istotny wpływ na wzrost znaczenia pozycji Polski w Europie, czego wyrazem było podporządkowanie pokonanego państwa zakonnego w Prusach i uzyskanie przez Polskę dominującej pozycji w Środkowej i Północnej Europie. Przede wszystkim jednak wydarzenia mające miejsce podczas wojny, zwłaszcza kryzys polityczny wywołany roszczeniami szlachty zebranej na wojnę w ramach pospolitego ruszenia i wydanie przywilejów dla szlachty w 1454 r., zainicjowały rozpoczęcie zmian w systemie politycznym Królestwa Polskiego, które doprowadziły do przekształceń w strukturach zgromadzeń stanowych i do powstania nowego układu władzy. Rezultatem zapoczątkowanych wówczas procesów przekształceń było powstanie w 1468 r. ogólnopaństwowego sejmu dwuizbowego, opartego na reprezentacji zgromadzeń terytorialnych, którego zwołanie nastąpiło zresztą wskutek konieczności rozwiązania problemów finansowych powstałych w następstwie wojny zakończonej w 1466 r. Wojna z lat 1454-1466 miała więc rzeczywisty wpływ na ukształtowanie się nowej konstrukcji ustrojowej Królestwa Polskiego, której rozwój kontynuowany był w XVI w.
\end{abstract}

Słowa kluczowe: wojna trzynastoletnia; system polityczny; sejm dwuizbowy; przywileje dla szlachty; Królestwo Polskie 